Chapter 20

\title{
Managing Alpine Forests in a Changing Climate
}

\author{
Peter Brang, Andrej Breznikar, Marc Hanewinkel, \\ Robert Jandl and Bernhard Maier
}

Additional information is available at the end of the chapter

http://dx.doi.org/10.5772/56272

\section{Introduction}

There is mounting evidence that Alpine forest ecosystems will not be able to fully absorb the changes in site factors associated with climate change, such as higher temperatures, more intensive drought stress and associated biotic impacts since these changes exceed the adaptive capacity of the trees. The projected changes in temperature by 2.2 to $5.1 \mathrm{~K}$ from 1980 to 1999 to 2080 to 2099, for the A1B scenario in southern Europe [1], correspond to an altitudinal shift of 300 to $700 \mathrm{~m}$ in a mountain landscape, if a lapse rate of 0.6 to $0.8 \mathrm{~K}$ per $100 \mathrm{~m}$ is assumed. Such altitudinal shifts are very often associated with a profound change in tree species composition. This climatic change is projected to occur within about 100 years and thus faster than the average lifetime of a tree in Alpine regions. Widespread tree mortality such as in many forests worldwide [2] is not an unrealistic scenario, and first signs of such phenomena were found in dry inner Alpine valleys [3].

Climatic change is also likely to profoundly alter biotic interactions between trees and pathogens, mostly in favor of the latter [4,5]. An example for negative impacts of climate change on forests is the devastative outbreak of mountain pine beetles in parts of Canada [4]. Large-scale tree mortality has affected the regional forest sector, but has also, at a global scale, influenced the political position of Canada towards climate change treaties. The forest sector, which for long had been a substantial $C$ sink, turned into a large $C$ source. The implications for the national greenhouse gas balance of Canada were such that Canada has withdrawn from the Kyoto Accord. In contrast to such negative effects of climate change on the forests' role as a $\mathrm{C}$ sink, there is increasing evidence for positive effects of higher temperatures on tree growth in cool environments [6] with abundant water supply and reasonable soil fertility.

Healthy forests are important for the timber industry and provide jobs in rural areas. Moreover, they are delivering numerous ecosystem services such as protection against natural hazards, 
carbon sequestration, drinking water, and habitat for a rich biodiversity of plants and animals. Managing Alpine space forests for these ecosystem goods and services in the face of a changing climate poses a number of novel challenges, which all increase the uncertainty in management. For instance, there is no recent guiding example for such rapid environmental change in forest ecosystems. The projected future site conditions are often not present in current landscapes, which means that analogies of potential future states are missing. Moreover, elevated rates of nitrogen deposition cause unprecedented trophic conditions at many sites [7]. The consequences of these remarkable changes which occur simultaneously and often interact are difficult to predict. The real adaptive capacity of the forest ecosystems, and in particular of the current generation of adult trees and of their offspring, are unclear. While ongoing research, e.g. in genetics of forest trees [8,9], is likely to reduce these uncertainties, forest practitioners will still need to make management decisions on the basis of incomplete knowledge and limited guidance.

In this uncertain situation, a 'change management' is needed which aims at ensuring that Alpine space forests continue to provide their goods and services, without major interruptions. Identifying and applying silvicultural strategies which can achieve this is the challenge for forest scientists and managers. Since the uncertainties are large, any management scheme should not be deterministic, but prepared for continuous readjustment, flexible and adaptive: designed to be adaptable to changes in the environmental factors, in the forest itself and also in changes in the anticipated further change.

The term 'adaptive management' (AM) [10-12] describes such a flexible management approach. AM should ensure continuous improvements through iterative cycles of planning, managing, monitoring, and revised planning. In contrast to traditional forest management, AM starts from the assumption that current knowledge about ecosystem functioning is limited and the future even more uncertain, and that current management approaches therefore need continuous revision. A critical element of AM is extensive stakeholder involvement. In many regions of the Alpine space this aspect still needs to be improved.

In this chapter, we want first to present current management approaches in Alpine forests. Second, we will outline adaptation measures which have been discussed, and are partly already being implemented. Third, we will examine how current management should be complemented with ideas from AM to enhance the adaptive capacity of Alpine space forests in the face of a changing climate.

\section{Silvicultural practices are diverse}

The silvicultural practices currently applied in Alpine space forests are highly diverse. The extremes are the intensive management of plantation forests, mostly of Norway spruce (Picea abies (L.) Karst.), or of coppice forests with short rotations, and the complete abandonment of any timber cutting on steep-slope forests with limited accessibility. However, management practices with moderate intensity prevail. Regeneration is often natural, stands are selectively thinned, cut sizes in final cuts are small (i.e. $<1$ ha), and substantial forest areas such as the 
whole of Slovenia and some Swiss regions are managed maintaining permanent forest cover in forestry $[13,14]$.

Silvicultural or forest management guidelines exist in several Alpine regions and countries. They have often been developed for use by forest managers of a specific region and are written in local languages (Table 1). Only the most recent guidelines among those listed do address adaptation to climate change. Some of the guidelines are also unpublished. For instance, the Slovenia Forest Service produced forest management guidelines for all forests, and part of regional forest management plans and plans for forest management units. It has also to be noted that there is usually a gap between guidelines and their practical implementation.

\section{Adaptation measures for Alpine space forests}

In the context of climate change, adaptation measures are measures that either decrease the probability of damage caused or triggered by climate change, exploit opportunities associated with climate change, or increase the adaptive capacity of the forests in the face of a changing climate. With adaptive capacity, we mean the ability of forest ecosystems to change continuously in composition and structure without breakdown (resistance, [26]) or to rebuild themselves, possibly with different composition and structure, after disturbances caused or triggered by climatic influences (resilience).

\begin{tabular}{|c|c|c|c|}
\hline Region & Domain of application & Scope & Reference \\
\hline Austria & Austrian national forests & $\begin{array}{l}\text { Silvicultural guidelines based on ecological } \\
\text { principles }\end{array}$ & {$[15]$} \\
\hline $\begin{array}{l}\text { Mühlviertel and Sauwald } \\
\text { (Upper Austria) }\end{array}$ & All forests of the region & $\begin{array}{l}\text { Tree species choice in the context of climate } \\
\text { change }\end{array}$ & {$[16]$} \\
\hline Vorarlberg (Austria) & All forests of Vorarlberg & $\begin{array}{l}\text { Description of forest types and silvicultural } \\
\text { guidelines }\end{array}$ & {$[17]$} \\
\hline $\begin{array}{l}\text { Baden-Württemberg } \\
\text { (Germany) }\end{array}$ & All forests of Baden-Württemberg & $\begin{array}{l}\text { Silvicultural guidelines based on forest } \\
\text { development types }\end{array}$ & {$[18]$} \\
\hline Bavaria (Germany) & Mountain forests of Bavaria & Silvicultural guidelines & {$[19]$} \\
\hline Bavaria (Germany) & Bavarian state forests & $\begin{array}{l}\text { Silvicultural guidelines in the face of climate } \\
\text { change }\end{array}$ & {$[20]$} \\
\hline Switzerland & All protection forests of Switzerland & $\begin{array}{l}\text { Hazard-and forest type-specific silvicultural } \\
\text { guidelines for protection forests }\end{array}$ & {$[21]$} \\
\hline $\begin{array}{l}\text { Canton of St. Gallen } \\
\text { (Switzerland) }\end{array}$ & All forests of the Canton St. Gallen & $\begin{array}{l}\text { Silvicultural guidelines in the face of climate } \\
\text { change }\end{array}$ & {$[22]$} \\
\hline Savoie (France) & Forests of the northern French Alps & Silvicultural guidelines for protection forests & {$[23]$} \\
\hline Southern Alps (France) & Forests of the southern French Alps & Silvicultural guidelines for protection forests & {$[24]$} \\
\hline Valle d'Aosta (Italy) & Pine forests in the eastern Alps & Silvicultural guidelines & {$[25]$} \\
\hline
\end{tabular}

Table 1. Selection of silvicultural guidelines for Alpine space forests. 
Many adaptation measures have been proposed (e.g. [12,27-31]). On a European level, more than 440 adaptation measures were compiled in a database [32]. No adaptation measures have been elaborated specifically for all Alpine space forests, which is not surprising since these forests are very diverse. Here, we describe four important adaptation measures, their justification and domain of application, and their probable effectiveness.

\subsection{Adaptation measure 1: Increasing tree species richness by variable regeneration cuts, enrichment planting, tending, and controlling ungulate browsing}

This measure aims at enhancing tree species richness at the stand scale, or for maintaining it if it is already high. The main argument for high species richness is an increased resistance to disturbances such as drought or storm [33-36], and higher resilience once a disturbance has occurred [37]. This argument is sometimes called 'insurance hypothesis' [38]. Intimate species mixtures (Figure 1) can be achieved through diverse regeneration cuts which create diverse niches or seedlings [28]. Enrichment planting in young growth stands can also be used to increase species richness, as well as tending such stands to rescue rare species or those which are able to withstand a warmer and drier climate [28]. In most cases, a complete change of the tree species composition of a forest cannot be justified and must be considered as risky. Usually, this means doing without natural regeneration (and thus requires large investments) and assuming specific future site conditions (which are in practice not exactly known).

Increasing species richness can also be achieved by introducing new tree species. It has been shown that some species initially do very well in a new environment because they escape their enemies when being moved to a new range [39]. The combination of release from enemies and inherent growth ability produces a synergistic effect that explains initial high performance of invaders $[39,40]$. Due to its high productivity, tolerance to summer drought and long-term successful use in central Europe, the green subspecies of Douglas fir (Pseudotsuga menziesii spp. menziesii) is increasingly used as an alternative to Norway spruce. Mixtures of Douglas fir with other species may maximize the delivery of ecosystem services such as timber production and carbon sequestration [41]. Other tree species are currently tested in new planting trials [42].

Increasing species richness may also involve correcting mistakes of the past. In the Alpine Space, man-made Norway spruce forests have often replaced former mixed beech (Fagus sylvatica L.) and silver fir (Abies alba (Mill.) L.) forests. These artificial forests are vulnerable to windthrow, pest outbreaks, drought and soil deterioration, and their conversion to more natural mixed-species stands [43,44], e.g. by underplanting of broadleaved trees [45], helps to make them more resistant to a warmer and drier climate.

Measures to increase species richness are most effective if applied in the regeneration and young growth stages. During the pole and timber tree stages, the potential for adjusting species richness is restricted to maintaining those species that have not been lost in earlier stages of stand development [28].

In the Alpine region, with is large altitudinal gradients and large forest cover, the preconditions for unassisted migration of the existing tree species are generally good. Relatively fast upslope migration, following the rising temperatures, should be possible for many tree species [46]. A 


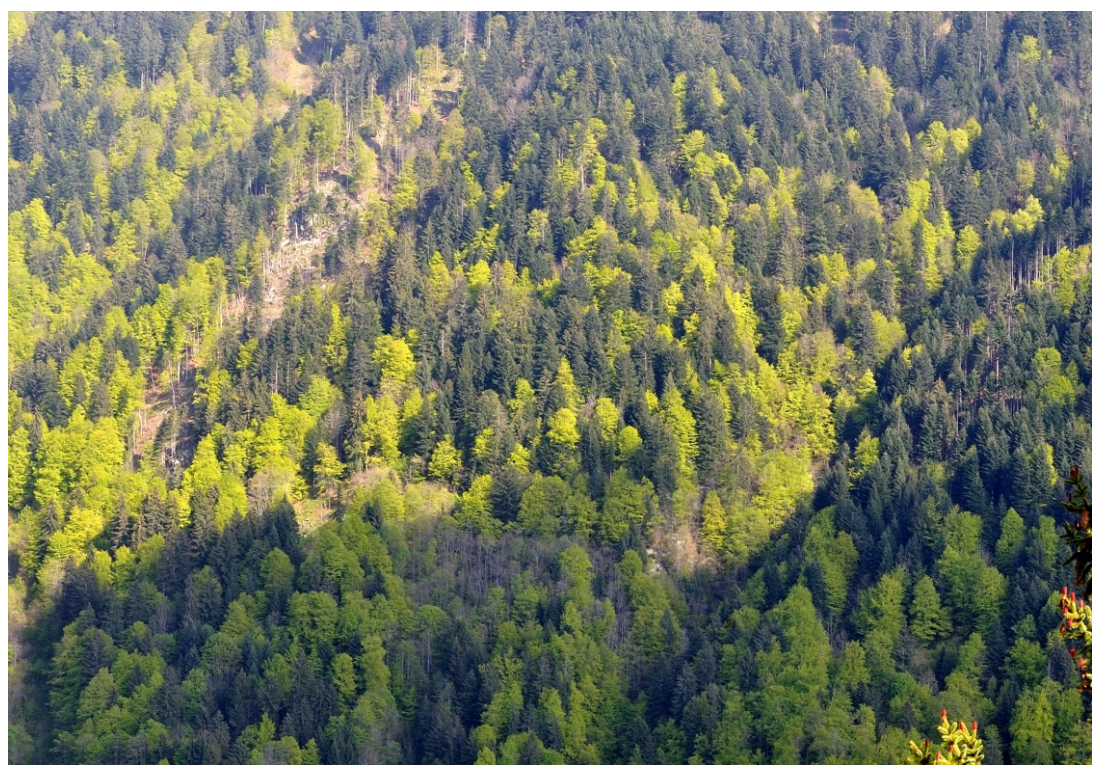

Figure 1. Mixed steep-slope forests with Norway spruce, silver fir, sycamore, ash and beech. Montreux, Switzerland, 1100 m a.s.l.

problem may occur near valley bottoms where species from warmer and drier climates may need to migrate over larger distances and even over mountains.

An important obstacle to high species richness is ungulate browsing $[47,48]$, which also often limits enrichment planting. In many regions the forests are under pressure from browsing ungulates, and hunting objectives are not aligned with forest management. Selective browsing inhibits the development of additional stand-stabilizing tree species, and the entire discussion on the benefits of mixed species forests remains futile.

It must to be noted that the species adapted for future climates are often less competitive in the current climate, e.g. sessile oak (Quercus petraea (Mattuschka) Liebl.) in beech thickets, which makes their maintenance by tending costly. Moreover, for vast high-altitude Alpine forests, the number of tree species able to thrive in these cold environments is currently limited to one or two species, e.g. Norway spruce or larch (Larix decidua L.) and Swiss stone pine (Pinus cembra L.).

\subsection{Adaptation measure 2: Increasing genetic diversity by natural regeneration, long regeneration periods and mixing provenances}

It is currently difficult to predict to what degree current tree populations are able to absorb climate change. Their phenotypic plasticity $[8,49]$ may be large, but insufficient if the environmental change occurs too quickly [50]. Natural regeneration coupled with long regeneration periods (Figure 2)is well suited to regenerate stands with a high seedling density from many 
mother trees [51,52], and thus to ensure large genetic variation. Enriching existing populations with provenances from other sites, usually drier and warmer sites, may also increase genetic diversity. However, this seems rather a measure for the future since it is not well established for which species and with which provenances this may be most effective. Like the first adaptation measure, increasing genetic diversity focuses on the regeneration and young growth stages.

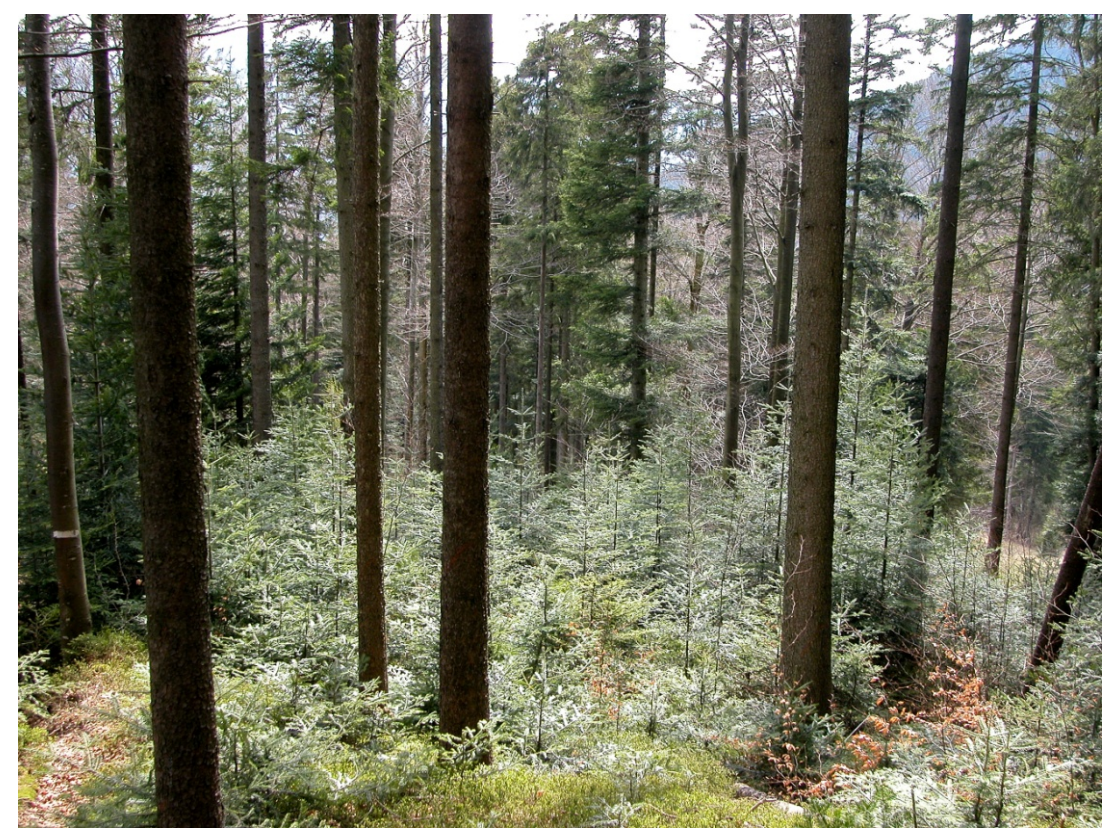

Figure 2. Long regeneration periods promote genetic diversity of the new generation. Small gap in a silver fir-Norway spruce stand with natural regeneration, Aegeri, Switzerland, $1100 \mathrm{~m}$ a.s.l.

\subsection{Adaptation measure 3: Increasing structural diversity by single-tree selection, target- diameter or conversion cutting}

Stands composed of trees with different age and size are structurally diverse either vertically in canopy layers or horizontally in adjacent patches. High structural diversity reduces the probability of stand-replacing disturbances, which may, in protection forests, entail the complete loss of the protective effect. For instance, storms affect small trees less likely than large ones (e.g. [53], or bark beetles may only attack trees of a certain size range. Moreover, vertically structured stands are more resilient after disturbance since advance regeneration will quickly be released [21]. Silvicultural measures to increase structural diversity are well established [43,44], but may entail increment losses [44] and trigger disturbances since they impair stand resistance, in particular to wind and snow break. The advantages of high structural diversity, in particular vertically, are considerable in forests where permanent cover 
is needed such as in steep-slope protection forests [54], but may be less important in timber production forests. Measures to increase structural diversity are applicable to all developmental stages apart from young growth (Figure 3). A change of the silvicultural system from even-aged to uneven-aged silviculture is, however, not justified as response to climate change alone, but should rather be based on other lines of argument [28].

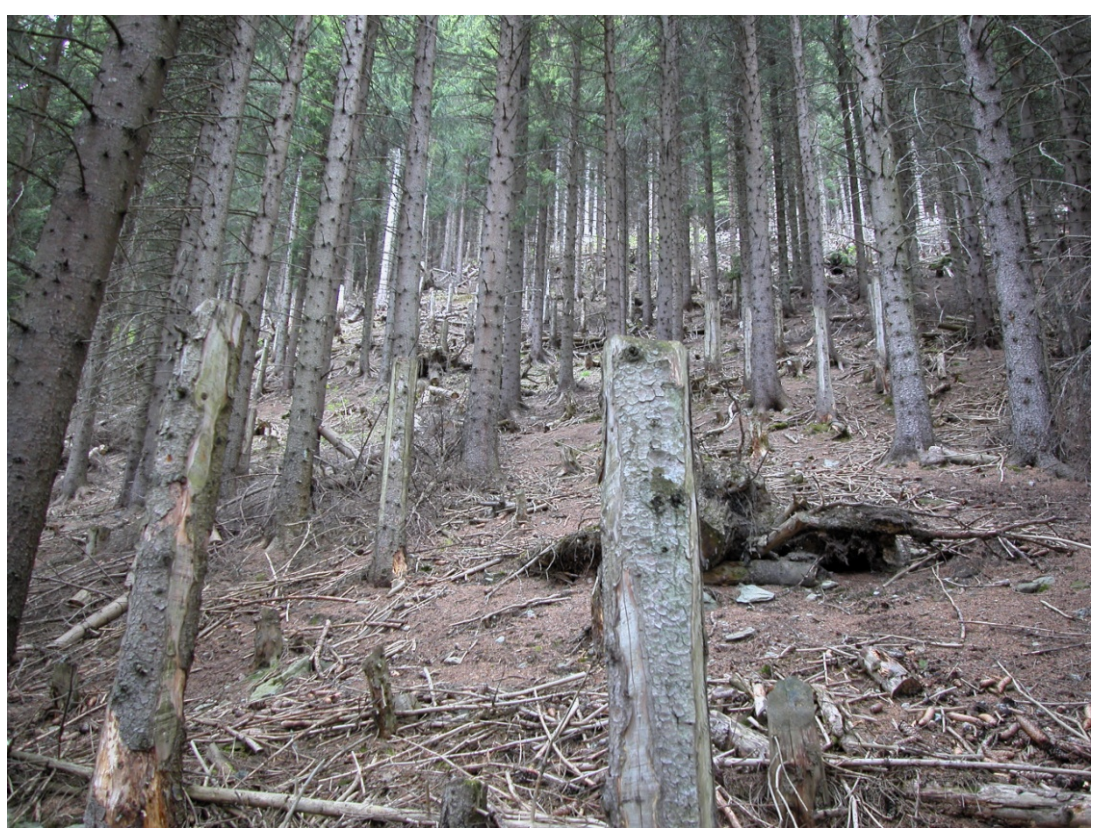

Figure 3. Conversion thinning in an homogeneous Norway spruce afforestation. The intervention aims at promoting structural heterogeneity by very small patch cuts. High stumps are left to prevent snow gliding. Tschamutt, Switzerland, $1600 \mathrm{~m}$ a.s.l.

\subsection{Adaptation measure 4: Reducing rotation length}

Old stands are more vulnerable to disturbance, in particular by wind, since susceptibility is correlated with stand height $[53,55-56]$ which in turn is correlated with stand age. Shorter rotation lengths or even premature felling are a preventive measure in stands with high disturbance risks (Figure 4) and can reduce damage [28]. A shorter rotation length may also be a measure to adapt to faster growth associated with higher temperature in cool environments, and with high inputs of atmospheric nitrogen. 


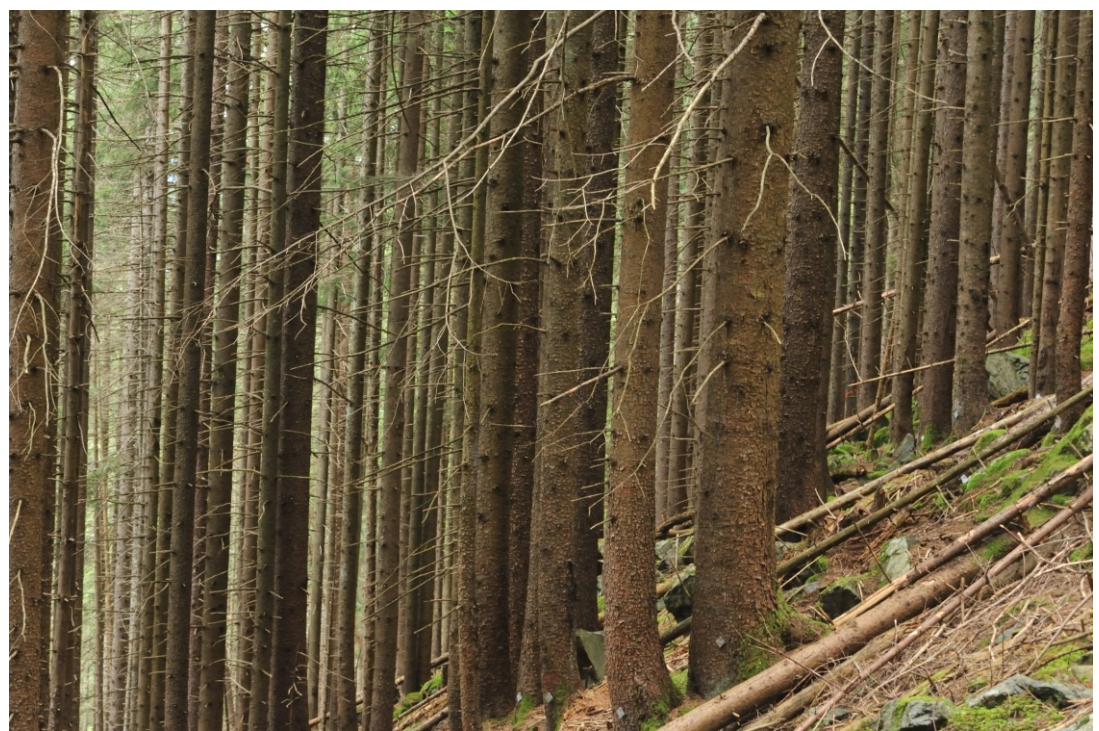

Figure 4. An unstable pure Norway spruce afforestation: a candidate stand for reduced rotation length. Gaschurn, Austria, $980 \mathrm{~m}$ a.s.l.

Among the four adaptation measures presented here, the first (increasing species richness) is probably most effective since species largely differ in their reaction to many site factors. Increasing species richness is also often mentioned in management guidelines $[16,20,22]$. The second adaptation measure (increasing genetic diversity) seems premature for widespread application, the third (increasing structural diversity) most effective in steep-slope protection forests, and the forth (reducing rotation length) restricted to stands with high disturbance risks.

\section{Towards the implementation of adaptive management}

$\mathrm{AM}$ as presented in the first section of this chapter, as a process of continuous improvements through iterative cycles of planning, managing, monitoring, and revised planning, is not currently practiced in the Alpine Space in a systematic manner. However, some elements of $\mathrm{AM}$ are increasingly adopted since its advantages are obvious in a situation with high uncertainty. One such element of AM are repeated forest inventories, which are established means of monitoring in many regions of the Alpine space. Another element is the increased use of silvicultural training plots [21]. However, practicioners still carry out many silvicultural tests without proper design and documentation, which largely limits their usefulness. 
A general barrier to the implementation of $\mathrm{AM}$ is a widespread skepticism to scientific evidence. This attitude is understandable since science is, for many practicioners, a blackbox, in particular when it comes to modeling. Moreover, scientific results reflecting general largescale phenomena and future trends often contradict the local observed development. This skepticism cannot easily be overcome, and is even partly a reasonable attitude since scientists, which are trained to focus on details and often lack a realistic perception of the management context, tend to over-interpret their findings. However, a strong belief in a large adaptive capacity of forests, based on past experience, must also be questioned. For instance, increased fire hazard on the northern slopes of the Alps and invasions of pathogens are quite likely [57, 58], but difficult to believe in the absence of past evidence.

A strategy of maintenance of existing forest structures, as response to a changing climate, seems risky since it is based on three assumptions which may prove wrong: i) small adverse impacts of climate change, ii) high stand resistance to climatic stress and iii) a high likelihood that silvicultural interventions will help to maintain forest structure [12]. The strategy of 'passive adaptation' [12], which means to suspend planned management interventions and to rely on spontaneous adaptation processes, i.e. natural succession and species migration, seems equally risky. These two strategies may be appropriate for forests with low economic importance or with no or only little protection function. However, if we assume more severe climate scenarios such as the A1B or A1F1 scenario [1], and if important production or protection functions are at stake, which is often the case in Alpine space forests, an active adaptation strategy [12] seems more appropriate.

Given the large uncertainties associated with climate change impacts on Alpine forests, we do at present not advocate large investments in adaptation measures with uncertain effectiveness [28]. Yet, total in-action is also inappropriate. The changes imposed by climate change are of a magnitude that calls for open-mindedness and readiness to revise existing management concepts. Conversely, simple silvicultural rules such as 'I rely on natural regeneration only', 'I use only native species' or 'I never use premature felling' seem unwise since they largely restrict the range of management tools which can be used to influence forest development, and to ensure the provision of ecosystem services.

Rather than already prescribing unconsolidated new silvicultural rules, capacity building efforts in the forest community, in interaction with stakeholders, seem important. This is crucial for the implementation of adaptive management which also involves systematic testing of alternative silvicultural treatments and success monitoring, but in less depth than commonly used in research. This creates a new task for researchers as they should support the implementation of AM by managers. The implementation of simple field tests and systematic monitoring of outcomes requires robust protocols and systematic documentation [59]. This task is new to many forest managers, and needs support from research. This is also new for many scientists and requires a thorough understanding not only of forest ecosystem dynamics, but also of the decision-making process including the information available to the other stakeholders involved and their interests, beliefs and attitudes.

Research can play an important role in AM. Current research in forest management is focusing on predicting impacts of future climates on tree species composition, forest dynamics, and the 
resulting consequences for forest products (in particular timber) and services. The phenotypic plasticity of trees in a changing climate is studied in genetics. Powerful simulation models enable reviewing our understanding of complex interactions in forest ecosystems, and testing management strategies assuming different climate scenarios. All these efforts are likely to provide important contributions to the revision of existing decision-making tools needed in the context of a changing climate, or the creation of new ones.

\section{Conclusions}

Climate change poses a novel challenge for forest science and management. AM as defined in this chapter seems particularly suitable to deal with the large uncertainty involved. Forest managers should increasingly see themselves as part of a learning community and perceive the establishment, maintenance and documentation of silvicultural field tests as part of their core business. Capacity building will also help to overcome simplistic management rules, and the resulting awareness for climate change issues is a precondition for acceptance of increased monitoring efforts, which will be needed for early detection of climate change impacts, including new pests and diseases. In particular regarding these transnational issues, crossborder networking is necessary.

In any adaptation strategy, it is also important to correctly weigh different problems. For instance, ungulate browsing $[47,48]$ may completely prevent putting increased tree species richness into practice.

The adaptation measures recommended in this chapter must be regarded as preliminary. The uncertainty about climate development and associated reactions of the forest is large, in particular with regard to disturbances and biological invasions. This calls for robust strategies which are likely to ensure the delivery of ecosystem products and services for different outcomes, preparedness for surprise, and a flexible and adjustable management approach.

\section{Author details}

Peter Brang ${ }^{1 *}$, Andrej Breznikar², Marc Hanewinkel ${ }^{1}$, Robert Jandl ${ }^{3}$ and Bernhard Maier ${ }^{4}$

*Address all correspondence to: brang@wsl.ch

1 WSL Swiss Federal Institute of Forest, Snow and Landscape Research, Birmensdorf, Switzerland

2 Slovenia Forest Service, Ljubljana, Slovenia

3 Institute of Forest Ecology, Austrian Forest Research Center (BFW), Vienna, Austria

4 Stand Montafon, Schruns, Austria 


\section{References}

[1] Solomon, S, Qin, D, Manning, M, Chen, Z, Marquis, M, Averyt, K. B, Tignor, M, \& Miller, H. L. editors. Contribution of Working Group I to the Fourth Assessment Report of the Intergovernmental Panel on Climate Change. Cambridge, United Kingdom and New York, NY, USA: Cambridge University Press; (2007).

[2] Allen, C. D, Macalady, A. K, Chenchouni, H, Bachelet, D, Mcdowell, N, Vennetier, M, Kitzberger, T, Rigling, A, Breshears, D. D, Hogg, E. H, Gonzalez, P, Fensham, R, Zhang, Z, Castro, J, Demidova, N, Lim, J. H, Allard, G, Running, S. W, Semerci, A, \& Cobb, N. A global overview of drought and heat-induced tree mortality reveals emerging climate change risks for forests. Forest Ecology and Management (2010). , 259(4), 660-684.

[3] Dobbertin, M, Wermelinger, B, Bigler, C, Bürgi, M, Carron, M, Forster, B, Gimmi, U, \& Rigling, A. Linking increasing drought stress to Scots pine mortality and bark beetle infestations. The scientific world journal(2007). , 7, 231-239.

[4] Kurz, W. A, Dymond, C. C, Stinson, G, Rampley, G. J, Neilson, E. T, Carroll, A. L, Ebata, T, \& Safranyik, L. Mountain pine beetle and forest carbon feedback to climate change. Nature (2008). , 452, 987-990.

[5] Engesser, R, Forster, B, Meier, F, \& Wermelinger, B. Die Bedeutung von forstlichen Schadorganismen im Zeichen des Klimawandels. Schweizerische Zeitschrift für Forstwesen (2008). , 159(10), 344-351.

[6] Leal, S, Melvin, T. M, Grabner, M, Wimmer, R, \& Briffa, K. R. Tree-ring growth variability in the Austrian Alps: The influence of site, altitude, tree species and climate. Boreas (2007). , 36(4), 426-440.

[7] Butterbach-Bahl, K, Nemitz, E, \& Zaehle, S. Nitrogen as a threat to the European greenhouse balance. In: Sutton MA, Howard CM, Erisman JW, Billen G, Bleeker A, Grennfelt P, van Grinsven H, Grizzetti B, editors. The European Nitrogen Assessment. Cambridge: Cambridge University Press; (2011). , 434-462.

[8] Kapeller, S, Schüler, S, Kraigher, H, Huber, G, Karopka, M, Wohlgemuth, T, \& Colin, E. Provenance trials in Alpine range- review and perspectives for applications in climate change. In: Cerbu G, editor. Management strategies to adapt Alpine space forests to climate change risks. Rijeka: InTech; (2012).

[9] Wang, T, Hamann, A, Yanchuk, Y, Neill, O, \& Aiken, G. S. Use of response functions in selecting lodgepole pine populations for future climates. Global Change Biology (2006). , 12, 2404-2416.

[10] Holling, C. S. Adaptive Environmental Assessment and Management. Chichester: John Wiley \& Sons; (1978). 
[11] Spittlehouse, D. L, \& Stewart, R. B. Adaptation to climate change in forest management. BC Journal of Ecosystems and Management (2003). 4(1) 1-11

[12] Bolte, A, Ammer, C, Lof, M, Madsen, P, Nabuurs, G. J, Schall, P, Spathelf, P, \& Rock, $\mathrm{J}$. Adaptive forest management in central Europe: Climate change impacts, strategies and integrative concept. Scandinavian Journal of Forest Research (2009). , 24, 473-482.

[13] Schütz, J. P. Geschichtlicher Hergang und aktuelle Bedeutung der Plenterung in Europa. Allgemeine Forst- und Jagdzeitung (1994). ; 165(5-6) 106-114

[14] Pommerening, A, \& Murphy, S. A review of the history, definitions and methods of continuous cover forestry with special attention to afforestation and restocking. Forestry (2004). , 77, 27-44.

[15] Weinfurter, P. Waldbauhandbuch. Eine Orientierungshilfe für die Praxis. Österreichische Bundesforste AG; (2004).

[16] Jasser, C, \& Diwold, G. Baumartenwahl im Mühlviertel- Empfehlungen für das Wuchsgebiet Mühlviertel und Sauwald. Oberösterreichische Landesregierung; (2011).

[17] Amann, G, Schennach, R, Kessler, J, Maier, B, \& Terzer, S. Handbuch der Vorarlberger Waldgesellschaften. Gesellschaftsbeschreibungen und waldbaulicher Leitfaden. Amt der Vorarlberger Landesregierung. Abteilung Forstwesen; (2010).

[18] Ministerium Ländlicher Raum Baden-Württembergeditor. Richtlinie landesweiter Waldentwicklungstypen. Stuttgart; (1999).

[19] Bayerisches Staatsministerium für ErnährungLandwirtschaft und Forsten, editor. Grundsätze für die Waldbehandlung im bayerischen Hochgebirge; (1982).

[20] Bayerische Staatsforsten, editor. Waldbauhandbuch Bayerische Staatsforsten. Bewirtschaftung von Fichten- und Fichtenmischbeständen im Bayerischen Staatswald (Stabilität- Strukturreichtum- Klimaanpassung). Regensburg: Bayerische Staatsforsten; (2008).

[21] Frehner, M, Wasser, B, \& Schwitter, R. Sustainability and success monitoring in protection forests. Guidelines for managing forests with protective functions. Partial translation by Brang P, Matter C. Environmental Studies (2007).

[22] Kantonsforstamt St. Gallen, editor. Waldpflege und Waldverjüngung unter dem Aspekt der Klimaveränderung. Strategiepapier. Empfehlungen des Forstdienstes des Kantons St.Gallen; (2008).

[23] Gauquelin, X, \& Courbaud, B. Guide des sylvicultures de montagne- Alpes du nord françaises. Grenoble: Cemagref, ONF; (2006). 289 p.

[24] Ladier, J, Rey, F, Calès, G, Simon-teissier, S, \& Quesney, T. Guide des Sylvicultures de Montagne pour les Alpes du Sud françaises. 1. Gestion des forêts à rôle de protection contre les aléas naturels. Paris: ONF; (2012). 135 p. 
[25] Vacchiano, G. editor. Il deperimento del Pino silvestre nelle Alpi occidentali: natura ed indirizzi di gestione. Arezzo: Regione Piemonte, Regione Autonoma Valle d'Aosta, Compagnia delle Foreste; (2008). 128 p.

[26] Grimm, V, \& Wissel, C. Babel, or the ecological stability discussions: an inventory and analysis of terminology and a guide for avoiding confusion. Oecologia (1997). , 109(3), 323-334.

[27] Millar, C. I, Stephenson, N. L, \& Stephens, S. L. Climate change and forests of the future: managing in the face of uncertainty. Ecological Applications (2007). , 17(8), 2145-2151.

[28] Brang, P, Bugmann, H, Bürgi, A, Mühlethaler, U, Rigling, A, \& Schwitter, R. Klimawandel als waldbauliche Herausforderung. Schweizerische Zeitschrift für Forstwesen (2008). , 159, 362-373.

[29] Lindner, M, Maroschek, M, Netherer, S, Kremer, A, Barbati, A, Garcia-gonzalo, J, Seidl, R, Delzon, S, Corona, P, Kolstrom, M, Lexer, M. J, \& Marchetti, M. Climate change impacts, adaptive capacity, and vulnerability of European forest ecosystems. Forest Ecology and Management (2010). , 259(4), 698-709.

[30] FAO, editor. Forests and climate change. Rome: Food and Agriculture Organization; (2012).

[31] Lexer, M. J. Waldwirtschaft im Klimawandel- ein Hintergrundbericht der CIPRA. Schaan: CIPRA; (2012).

[32] Kolström, M, Lindner, M, Vilén, T, Maroschek, M, Seidl, R, Lexer, M. J, Netherer, S, Kremer, A, Delzon, S, Barbati, A, Marchetti, M, \& Corona, P. Reviewing the science and implementation of climate change adaptation measures in European forestry. Forests (2011). , 2(4), 961-982.

[33] Von Lüpke, B, \& Spellmann, H. Aspects of stability, growth and natural regeneration in mixed Norway spruce-beech stands as a basis of silvicultural decisions. In: Olsthoorn AFM, Bartelink HH, Gardiner JJ, Pretzsch H, Hekhuis HJ, Franc A, Wall S. (eds) Management of mixed-species forest: silviculture and economics. Wageningen: DLO Institute for Forestry and Nature Research (IBN-DLO); (1999). , 245-267.

[34] Schütz, J. P, Götz, M, Schmid, W, \& Mandallaz, D. Vulnerability of spruce (Picea abies) and beech (Fagus sylvatica) forest stands to storms and consequences for silviculture. European Journal of Forest Research (2006). , 125, 291-302.

[35] Knoke, T, Ammer, C, Stimm, B, \& Mosandl, R. Admixing broadleaved to coniferous tree species: a review on yield, ecological stability and economics. European Journal of Forest Research (2008). , 127, 89-101.

[36] Puettmann, K. J, Coates, K. D, \& Messier, C. A critique of silviculture- managing for complexity. Washington, Covelo, London: Island Press; (2009). 
[37] Brang, P. Resistance and elasticity: promising concepts for the management of protection forests in the European Alps. Forest Ecology and Management (2001). 145(1-2) 107-119

[38] Pretzsch, H. Diversity and productivity in forests: evidence from long-term experimental plots. In: Scherer-Lorenzen M, Körner C, Schulze E-D, (eds.) Forest diversity and function. Temperate and boreal systems. Ecological Studies 176. Springer, Berlin, Heidelberg, New York: Springer; (2005). , 41-64.

[39] Blumenthal, D, Mitchell, C. E, Pyšek, P, \& Jarošík, V. Synergy between pathogen release and resource availability in plant invasion. Proceedings of the National Academy of Sciences (2009). DOIpnas.0812607106, 106(19), 7899-7904.

[40] Seastedt, T. Traits of plant invaders. Nature (2009). , 459, 783-784.

[41] Prietzel, J, \& Bachmann, S. Changes in soil organic C and N stocks after forest transformation from Norway spruce and Scots pine into Douglas fir, Douglas fir-spruce, or European beech stands at different sites in Southern Germany. Forest Ecology and Management (2012). , 269, 134-148.

[42] Schmiedinger, A, Bachmann, M, Kölling, C, \& Schirmer, R. Verfahren zur Auswahl von Baumarten für Anbauversuche vor dem Hintergrund des Klimawandels. Forstarchiv (2009). , 80, 15-22.

[43] Schütz, J. P. Opportunities and strategies of transforming regular forests to irregular forests. Forest Ecology and Management (2001). 151(1-3) 87-94

[44] Spiecker, H. Norway Spruce conversion- options and consequences. European Forest Institute Research Report (2004). , 18-269.

[45] Oleskog, G, \& Löf, M. The ecological and silvicultural bases for underplanting beech (Fagus sylvatica L.) below Norway spruce shelterwoods (Picea abies (L.) Karst.). Schriften aus der Forstlichen Fakultät der Universität Göttingen und der Niedersächsischen Forstlichen Versuchsanstalt (2005). J. D. Sauerländer's Verlag.

[46] Vitasse, Y, Hoch, G, Randin, C. F, Lenz, A, Kollas, C, \& Körner, C. Tree recruitment of European tree species at their current upper elevational limits in the Swiss Alps. Journal of Biogeography (2012). , 39(8), 1439-1449.

[47] Gill RMAA review of damage by mammals in north temperate forests. 1. Deer. Forestry (1992). , 65, 145-169.

[48] Gill RMAA review of damage by mammals in north temperate forests. 3. Impact on trees and forests. Forestry (1992). , 65, 363-388.

[49] Mátyás, C, \& Nagy, L. Ujvári Jármay É. Genetic background of response of trees to aridification at the xeric forest limit and consequences for bioclimatic modelling. Forstarchiv (2010). , 81, 130-141. 
[50] Hoffmann, A. A, \& Sgrò, C. M. Climate change and evolutionary adaptation. Nature (2010). , 470, 479-486.

[51] Finkeldey, R, \& Ziehe, M. Genetic implications of silvicultural regimes. Forest Ecology and Management (2004). 97(1-3) 231-244

[52] Finkeldey, R. Genetik, Ökologie, Forstwirtschaft: Zusammenhänge und Perspektiven. Schweizerische Zeitschrift für Forstwesen (2010). , 161(6), 198-206.

[53] Mayer, P, Brang, P, Dobbertin, M, Hallenbarter, D, Renaud, J-P, Walthert, L, \& Zimmermann, S. Forest storm damage is more frequent on acidic soils. Annals of Forest Science (2005). , 62, 303-311.

[54] Schönenberger, W, \& Brang, P. Silviculture in mountain forests. In: Burley J., Evans J (eds.). Encyclopedia of forest sciences. Amsterdam: Elsevier. (2004). , 1085-1094.

[55] Hanewinkel, M, Breidenbach, J, Neeff, T, \& Kublin, E. Seventy-seven years of natural disturbances in a mountain forest area- the influence of storm, snow and insect damage analysed with a long-term time series. Canadian Journal of Forest Research (2008). , 38(8), 2249-2261.

[56] Schmidt, M, Hanewinkel, M, Kändler, G, Kublin, E, \& Kohnle, U. An inventorybased approach for modeling single tree storm damage- experiences with the winter storm 1999 in southwestern Germany. Canadian Journal of Forest Research (2010). , 40(8), 1636-1652.

[57] Schumacher, S, Reineking, B, Sibold, J, \& Bugmann, H. Modeling the impact of climate and vegetation on fire regimes in mountain landscapes. Landscape Ecology(2006). , 21, 539-554.

[58] Seidl, R, Schelhaas, M-J, \& Lexer, M. J. Unraveling the drivers of intensifying forest disturbance regimes in Europe. Global Change Biology (2011). , 17-2842.

[59] Rosa, J, Riou-Nivert, P, Paillassa, E. Guide de l'expérimentation forestière. Principes de base. Prise en compte du changement climatique. Paris: CNPF/IDF. (2011). 
